\title{
Ethnobotany and Agrobiodiversity: Valuation of Plants in the Homegardens of Southwestern Uganda
}

\author{
Cory W. Whitney ${ }^{1,2^{*}}$, Joseph Bahati ${ }^{3}$, and Jens Gebauer ${ }^{1}$ \\ ${ }^{1}$ Rhine-Waal University of Applied Sciences, Faculty of Life Sciences, Kleve, Germany. ${ }^{2}$ University of Kassel, Faculty of \\ Organic Agriculture Sciences, Witzenhausen, Germany. ${ }^{3}$ Makerere University, College of Agricultural and Environmental \\ Sciences, Kampala, Uganda. \\ *cory.whitney@uni-bonn.de
}

\begin{abstract}
Homegardens are species-rich agroforestry systems with a high diversity of associated traditional knowledge. These systems are an important part of food security for rural marginalized poor around the world, particularly in the humid tropics. Despite the high diversity and cultural importance, little is known about the livelihood-relevant plant diversity contained in the homegardens of southwestern Uganda. Here we employ the quantitative ethnobotany indices use reports (UR) and the cultural importance index (Cl) to describe the importance of plants and plant types in the region's homegardens. Data is based on inventories of 102 homegardens in the Greater Bushenyi from 2014 and reveals 225 useful plant species in 14 different use categories with 3,961 UR, 54\% for food, 15\% for economic uses, and 11\% for medicine. The findings highlight the importance of homegarden plants for subsistence farming households and indicate that they are important places for conservation of botanical agrobiodiversity that should be considered part of the conservation movement in Uganda. Efforts to conserve both botanical and food system diversity in the extremely rich but rapidly deteriorating regional socio-cultural and ecological systems should consider homegardens for their role in conservation of plants and preservation of traditional knowledge.
\end{abstract}

Received October 17, 2015

OPEN ӘACCESS

Accepted December 14, 2017

DOI 10.14237/ebl.9.2.2018.503

Keywords Agroforestry, Conservation, Quantitative ethnobotany, Traditional knowledge

Copyright (c) 2018 by the author(s); licensee Society of Ethnobiology. This is an open-access article distributed under the terms of the Creative Commons Attribution-NonCommercial 4.0 International Public License (https://creativecommons.org/licenses/by-nc/4.0), which permits non-commercial use, distribution, and reproduction in any medium, provided the original author and source are credited.

\section{Introduction}

Homegardens are species-rich agroforestry systems containing many cultivated and wild plants (Kumar and Nair 2004). They have a unique vertical structure that is an important part of the productive capacity (Buyinza 2009; Niñez 1985; Figure 1). The homegardens of Uganda are ideal locations for the study of plant and human interactions regarding traditional knowledge and conservation (Figure 1). They are complex farming systems (Whitney et al. 2017) that have been optimized to meet multiple needs with high levels of plant diversity that maximize resources in environments with limited access to resources and markets (FAO 2011). The traditional plants that the homegardens contain are used primarily for food (FAO 2011). They grow in a wide diversity of farm niches (Eilu et al. 2007) close to homesteads and in young fallows (Tabuti et al. 2011). They act as risk insurance against environmen- tal stresses (FAO 2011) and are preferred for their high drought resistance, natural regeneration, ease of management, fast maturation, and plantlet availability (Tabuti 2012).

Still, there are many underutilized food plants in Uganda (Tabuti 2012). As homegardens in the region decline, mainly due to social and economic pressures (Buyinza 2009), more commercial crops are planted with more intensive management and species richness, leading to abundance decreases (Scales and Marsden 2008). Many traditional plants in such smallscale farming systems are in danger due to overharvesting, destructive harvesting, pests and diseases, and extreme weather such as droughts (Tabuti 2012).

Potential exists for the expansion of homegardens in Uganda and the subsequent promotion of plants as traditional food and nutrition, e.g., to encourage farmers to plant and utilize indigenous plants in circa 


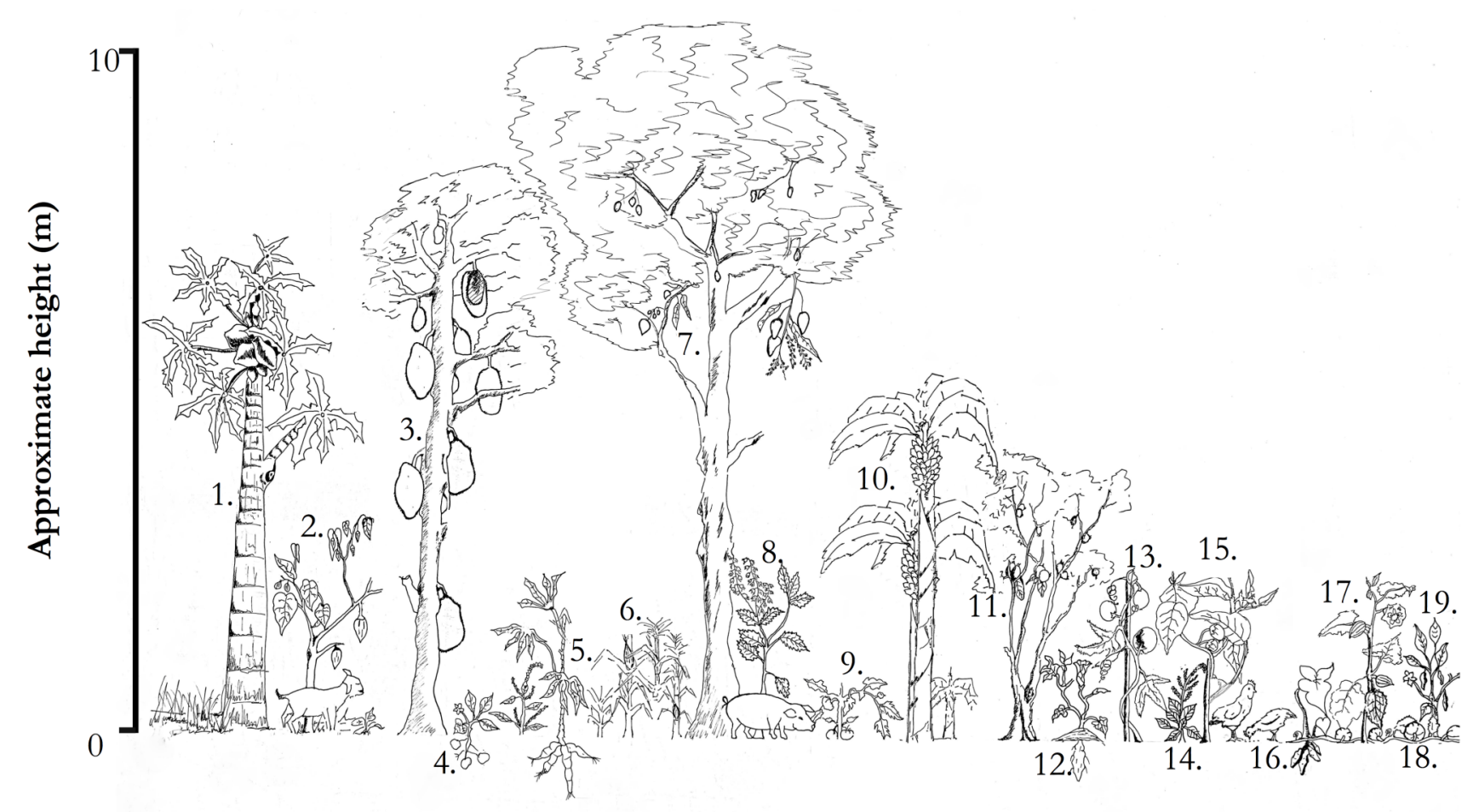

Figure 1 A typical multilayered Ugandan homegarden structure showing approximate heights for a diversity of edible species. Adapted from (Whitney et al. 2017) Artwork by Carolyne Nakaketo. Plants numbered: 1. Carica papaya, 2. Solanum betaceum, 3. Artocarpus heterophyllus, 4. Solanum tuberosum, 5. Manihot esculenta, 6. Zea mays, 7. Mangifera indica, 8. Ocimum gratissimum, 9. Solanum lycopersicum, 10. Musa spp., 11. Psidium guajava, 12. Ipomoea batatas, 13. Passiflora spp., 14. Amarathus spp., 15. Solanum aethiopicum, 16. Xanthasoma spp., 17. Physalis peruviana, 18. Cucurbita spp., and 19. Capsicum spp.

situm conservation (Tabuti et al. 2011) and thereby minimize future losses of native biodiversity (Scales and Marsden 2008). A better understanding of the dynamics of homegarden systems is essential to formulate these solutions so that they are ecologically sound, economically appropriate, and socially relevant (Buyinza 2009). Furthermore, as much of the traditional ethnobotany knowledge is held by the elderly and is in danger of not being transmitted to younger generations, there is a need to capture this knowledge before it is lost (Luoga et al. 2000; Tugume et al. 2016).

Quantitative indices in ethnobotany are important for assessing the livelihood-relevance of plants and thereby the relationships between people and the natural systems that surround and support them (Ahoyo et al. 2017; Prance et al. 1987; Whitney et al. 2014). The homegardens of Uganda are important examples of such systems. They contain a variety of plants with multiple uses and could be explored for their conservation relevance. The current investigation sought to assess the varied aspects of botanical species diversity and ethnobotanical knowledge (cf. Carlson and Maffi 2004; Alexiades and Sheldon 1996) and to describe the current species composition of homegarden cropping systems to provide baseline data for future work. The specific aim was to describe the ethnobotany of homegarden diversity and the relationship to different plant types. Such descriptions will allow future analysis of timerelated changes (cf. Bruelheide et al. 2003), assessment of the degree of genetic erosion (cf. Buerkert et al. 2006; Hammer and Laghetti 2005), and reveal potential interventions for conservation.

\section{Materials and Methods}

The homegardens investigated are in a collection of districts known as the Greater Bushenyi in the highlands of southwestern Uganda (Figure 2). The region's elevation ranges from valleys of $910 \mathrm{~m}$ and mountain peaks of $2,500 \mathrm{~m}$ above sea level. The natural botanical diversity is of a transitory zone between the tropical moist broadleaf forests of 

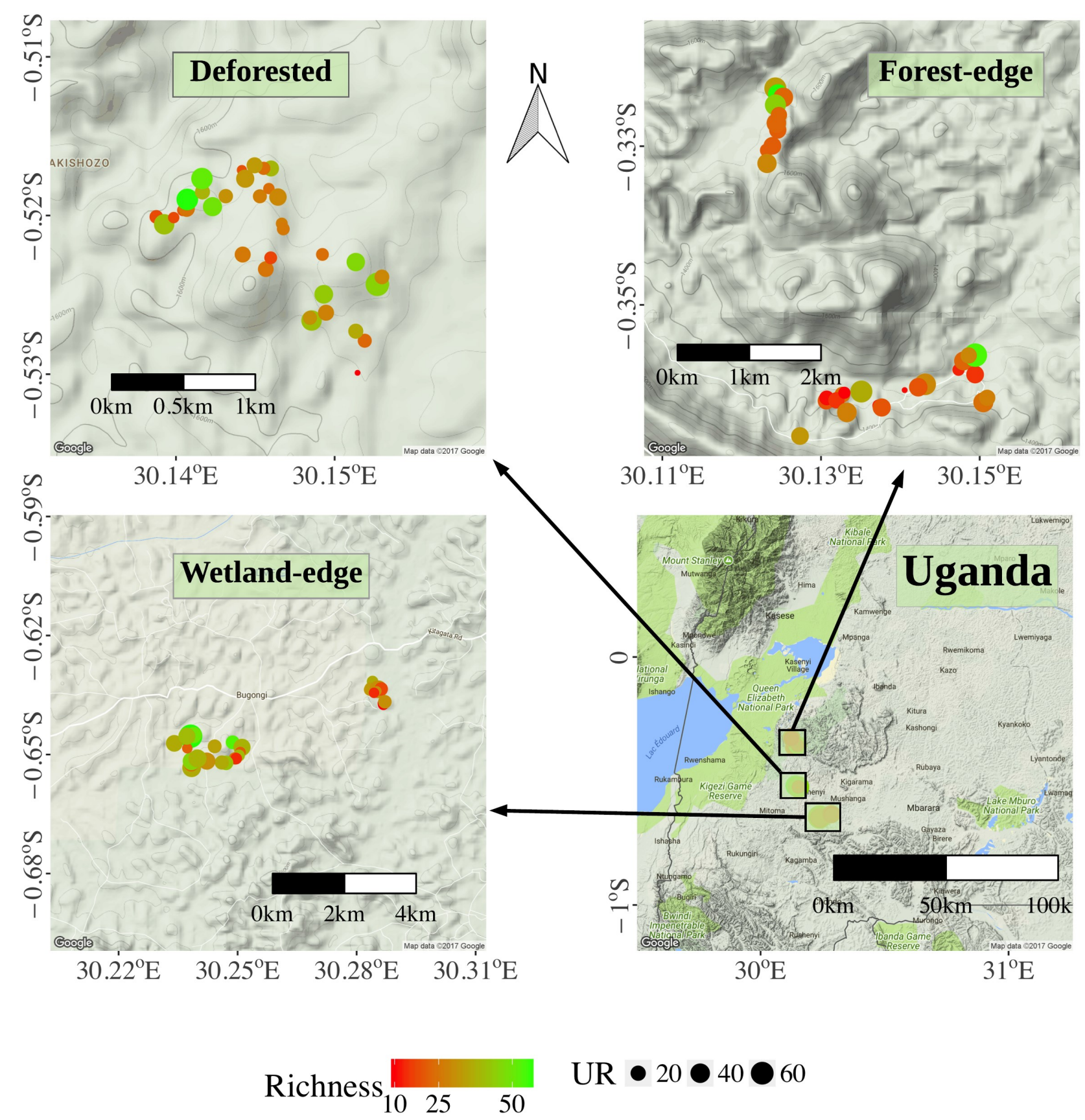

Figure 2 Map of 102 homegardens in forest-edge, wetland-edge, and recently deforested areas of Uganda's Greater Bushenyi Region showing plant species richness and use reports (UR) for plants. Map adapted from Whitney et al. (under review) and created using R's ggmap (Kahle and Wickham 2013).

equatorial Africa (Congolian forests) and the drier savannas and open woodlands of the forest belt, interspersed with the rich floral diversity of high altitude swamps (van Breugel et al. 2015). The region receives $1,500-2,000 \mathrm{~mm}$ rainfall a year and has mean annual temperatures between $12{ }^{\circ} \mathrm{C}$ and $30{ }^{\circ} \mathrm{C}$. Homegardens in the region are dominated by bananas and intercropped with coffee with a variety of staples, fruits, vegetables, medicinal plants, trees for fuel 
wood, with some additional livestock (Goode 1989; Oduol and Aluma 1990; Whitney et al. 2017).

We undertook ethnobotany fieldwork for this study as part of a larger regional homegarden assessment (Whitney et al. 2017). Nine villages were randomly selected through a stratified, random design along the forest-edge, wetland-edge, and recently deforested areas in the Greater Bushenyi. Randomized village selection was done with the help of Chief Administrative Offices of Greater Bushenyi and subsequent randomized homegarden selection was done with the help of the chairperson of each of the nine villages. Together we randomly selected eleven to twelve homegardens within each of the nine villages $(n=102)$ and visited each of them at the end of a rainy season in 2014.

Our approach was to gather ethnobotany information together with homegarden managers by following the walk-in-the-woods method (Phillips and Gentry 1993a, 1993b). Several visits were made to each household to generate a list of all useful plants in each homegarden (median richness $=27$, range $=10$ 57) and a complementary list of uses. Homegarden areas, locations, and cropping patterns were recorded during these visits via walk-through with GPS and map sketching (cf. Whitney et al. 2016).
Plant species of ethnobotanical importance (plants useful to farmers ${ }^{1}$ ) were recorded with scientific names as well as local Runyankole, Rukiga, and Luganda names and identified with the help of botanists from Makerere University, Kampala. Botanical specimens of all species were conserved in field presses for the collection of the Makerere University Herbarium (MHU). Plants were classified according to their life-forms (types), i.e., annual forbs and grasses, perennial forbs and grasses, shrubs, trees, palms, and vines (including all trailing and climbing plants) (see Whitney et al. 2017).

We used collaborative plant use categorization, based on the diversity of 14 different active plant uses among farmers: 1. food and drink, 2. economic uses, 3. medicine, 4. technical uses, 5. ornamental, 6. fencing, 7. firewood, 8. timber and building material, 9. shelter, 10. hygienic, 11. animal feed, 12. sharing, 13. pesticide, and 14. manure for soil fertility (Table 1). Distribution of UR across the different uses and plant types was plotted with the circlize package in $\mathrm{R}$ (Gu et al. 2014).

All data were uploaded digitally in the field and subsequently imported into the $\mathrm{R}$ programming environment ( $R$ Core Team 2016). Data were analyzed using quantitative ethnobotany indices

Table 1 Description of 14 use categories and sum of use reports (UR) and cultural importance index (CI) for 225 plants in 102 homegardens in southwest Uganda.

\begin{tabular}{lllll}
\hline Category & Description & UR & Ci & Plants* \\
\hline Food & Eating and drinking, food, juice, staples and casual foods, occasional & 2,145 & 2.337 & 136 \\
& foods & & & \\
Sale & Economic uses, sales and income generation & 604 & 0.658 & 67 \\
Med. & Medicinal uses for acute illnesses and general health & 426 & 0.464 & 142 \\
Tch. & Technical uses such as filtration for the wine production, brooms, & 267 & 0.291 & 74 \\
& tools, whipping sticks etc. & & & \\
Orn. & Ornamental, considered decorative or attractive (generally a second- & 150 & 0.163 & 51 \\
& ary use) & & & \\
Fnc. & Planted fences and fencing materials & 117 & 0.127 & 21 \\
Fir. & Firewood & 99 & 0.108 & 35 \\
Ti. & Timber and building materials & 44 & 0.048 & 20 \\
Shl. & Shade and shelter from wind and sun, storms & 34 & 0.037 & 25 \\
Hyg. & Hygiene, used to make soap and used for washing up & 33 & 0.036 & 19 \\
A. & Animal feed, generally goats, pigs and cows & 23 & 0.025 & 11 \\
S. & Shared and bartered, generally planted for the use of neighbors and & 13 & 0.014 & 11 \\
& children & & & \\
Pt. & Pesticide, against insects and other pests & 4 & 0.004 & 4 \\
M. & Manure, used for soil fertility, in compost, n-fixation, mulching and & 2 & 0.002 & 2 \\
& other soil nutrition uses & & & \\
\hline
\end{tabular}

*153 of the total of 225 plant species were cited in more than one category 
(Kufer et al. 2005; Phillips and Gentry 1993a, 1993b; Prance et al. 1987). Our analysis concentrated on two use values indices (Phillips and Gentry 1993a, 1993b; Prance et al. 1987). The first was the use report (UR), which we used to quantify ethnobotanical information to obtain values for the calculation of analytical indices. The total UR per species is the sum of all the times that individual respondents named the species for a specific use category and the sum of all those categories. For example, five farmers had Annona senegalensis, two of whom used it as a fruit, two for its medicinal leaves, one for technical uses, and one for its protection from wind and sun. This gave $A$. senegalensis a total UR of six although it was only present in five gardens.

We used the UR to calculate the cultural importance index (CI) (Tardío and Pardo-de-
Santayana 2008) for each species, to allow for the identification of the relative importance of different plant species. CI was calculated by dividing UR by the number of informants (Tardío and Pardo-deSantayana 2008).

\section{Results}

Findings based on the quantitative ethnobotany indices highlighted the importance of Ugandan homegarden plants for multiple livelihood uses for the 102 households interviewed. Respondents introduced 225 different plant species that were important for the family ${ }^{1}$. These were divided into the 14 different use categories leading to 3,961 UR. Median UR per homegarden was 16.5 , with a range of 2-65. Nearly half of all UR were for food (54\%), followed by economic uses (15\%) and medicine (11\%) (Table 1).

Table 2 The 30 plants with the highest cultural importance index (Cl) score and number of use reports (UR) in 102 homegardens in southwest Uganda.

\begin{tabular}{llll}
\hline Family & Botanical name & UR & CI \\
\hline Musaceae & Musa (AAA-EAHB Group) & 169 & 0.184 \\
Musaceae & Musa (AB Group) & 134 & 0.146 \\
Musaceae & Musa (AAA Group) & 131 & 0.143 \\
Asparagaceae & Draceana fragrans & 120 & 0.131 \\
Lauraceae & Persea americana & 120 & 0.131 \\
Musaceae & Musa (AAB Group) & 116 & 0.126 \\
Rubiaceae & Coffea canephora & 99 & 0.108 \\
Araceae & Xanthosoma sagittifolium & 95 & 0.103 \\
Myrtaceae & Psidium guajava & 88 & 0.096 \\
Poaceae & Saccharum officinarum & 88 & 0.096 \\
Euphorbiaceae & Manihot esculenta & 81 & 0.088 \\
Anacardiaceae & Mangifera indica & 80 & 0.087 \\
Leguminosae & Phaseolus vulgaris & 79 & 0.086 \\
Caricaceae & Carica papaya & 73 & 0.080 \\
Cucurbitaceae & Cucurbita pepo & 71 & 0.077 \\
Moraceae & Artocarpus heterophyllus & 71 & 0.077 \\
Solanaceae & Solanum aethiopicum & 69 & 0.075 \\
Solanaceae & Solanum anguivi & 65 & 0.071 \\
Passifloraceae & Passiflora edulis & 65 & 0.071 \\
Solanaceae & Solanum lycopersicum & 61 & 0.066 \\
Bromeliaceae & Ananas comosus & 58 & 0.063 \\
Myrtaceae & Eucalyptus grandis & 58 & 0.063 \\
Rosaceae & Eriobotrya japonica & 55 & 0.060 \\
Solanaceae & Physalis peruviana & 55 & 0.060 \\
Solanaceae & Capsicum frutescens & 54 & 0.059 \\
Amaranthaceae & Amaranthus hybridus & 52 & 0.057 \\
Euphorbiaceae & Euphorbia tirucalli & 51 & 0.056 \\
Rubiaceae & Coffea arabica & 49 & 0.053 \\
Musaceae & Musa (ABB Group) & 48 & 0.052 \\
Amaranthaceae & Amaranthus dubius & 45 & 0.049 \\
\hline & & &
\end{tabular}


The 30 plants with the highest CI score (0.049 or greater) included 4 annuals and 11 perennials, 1 liana, 8 shrubs and 6 trees. Those plants with higher CI scores were used for multiple purposes across several homegardens (e.g. Musa2 Solanum and Xanthosoma spp.) (Table 2). Notably, the gathering of these data required a considerable amount of trust, patience, and time, since some of the farmers were traditional healers who were guarded about their traditional plant names and uses.

The diversity of uses of plant types across different use categories is an indication of the importance of these plant types for ethnobotany and biodiversity (Figure 3). UR was rather evenly spread for trees and shrubs, whereas, forbs, herbs, and other plants had many uses in a single category.

The homegardens contained a total richness of 66 species of useful perennial forbs with a total UR of 530 and a range of $0-4$ UR per garden. They also contained 59 species of trees with a total UR of 512 (range 0-5), 54 shrubs (total UR $=655$, range 0-4), 22 annual forbs (total UR $=95$, range $0-4$ ), 14 vines (total UR $=46$, range $0-4$ ), six perennial grasses (total $\mathrm{UR}=8$, range $0-5$ ), three annual grasses (total $\mathrm{UR}=$ 13 , range $0-1$ ), and a single species of palm, wild date palm (Phoenix reclinata), with two UR (technical and ornament) (Figure 3).

\section{Discussion and Conclusions}

Our findings illustrate the multipurpose nature of homegarden botanical diversity. This echoes some of the results of past studies that point to the role of plant genetic diversity as a factor differentiating plants in homegardens from those in the fields (Gessler and Hodel 2010). This distinction may be especially important when considering the value of cultivated diversity beyond purely economic measurements.

Our use of the well-established quantitative ethnobotany use value indices UR and CI (Kufer et al. 2005; Phillips and Gentry 1993a, 1993b; Prance et al. 1987; Tardío and Pardo-de-Santayana 2008), allowed us to gather comparable baseline data. The most versatile of all the plants in the study included six trees and eight shrubs (Table 2). These, together with other woody species, accounted for a large portion of the total species found (59 trees and 54 shrubs; Figure 3 ), and for $33 \%$ and $26 \%$ of UR respectively. This was similar to past ethnobotany studies in Uganda showing the importance of 29 woody species for benefits to the environment and future generations, and as building materials, firewood, food, medicine, sales, shade, soil amendments, timber, and as a wind break in the west (Nyamukuru et al. 2015), and 51 woody plants used mostly for construction, energy, food, foraging, medicine (human and veterinary), and technology in the east (Tabuti 2012). Similarly, in eastern Tanzania 133 woody species were used for charcoal, firewood, medicine, and poles (Luoga et al. 2000), and in the central region of Benin, 79 woody species were used for bark-cloth, charcoal, firewood, foraging, fruit, income, medicine, poles, shade, and timber (Ahoyo et al. 2017).

The 225 useful plant species in the homegardens fit into 14 different use categories, the most important of which was food (CI 2.3; Table 1). These findings also concur with past studies regarding the importance of Ugandan homegardens for food and nutrition security (Remans et al. 2011; Whitney et al. under review).

Many of the plant species in this study were also used for medicinal purposes (142 species, $11 \%$ of UR; Table 1). This finding is similar to an ethnobotany study of traditional healers and herbal medicine collectors in Central Uganda who used 190 medicinal species (Tugume et al. 2016), a study of families in southwest Kenya, which found 330 medicinal species (Johns et al. 1990), and an ethnobotany study of semipastoralists in southern Ethiopia who used more than the 57 medicinal species (Teklehaymanot and Giday 2010). This was also similar to an ethnobotany survey in Northern Cape Province, South Africa, which found 64 species with a variety of uses, many of which were medicinal (De Beer and Van Wyk 2011). These useful plants were divided among many layers of the homegarden vertical structure (Figure 1).

Whitney et al. (2017) describes the vertical structure of the region's homegardens according to plant life-form types. Trees form an upper layer; shrubs form a second layer together with perennial forbs and vines; and other perennial and annual forbs form two lower layers (cf. Figure 1). Our findings show that these different plant types have distinct ethnobotany importance. Trees and shrubs were distributed relatively evenly across a variety of uses (seven and 12 use categories respectively; Figure 3). Other plant types were less diverse, e.g., $78 \%$ of UR for annual forbs and 59\% of UR for perennial forbs were in the single use category food (Figure 3). These findings offer insights into the dual ecological and cultural role that woody plants play in the 


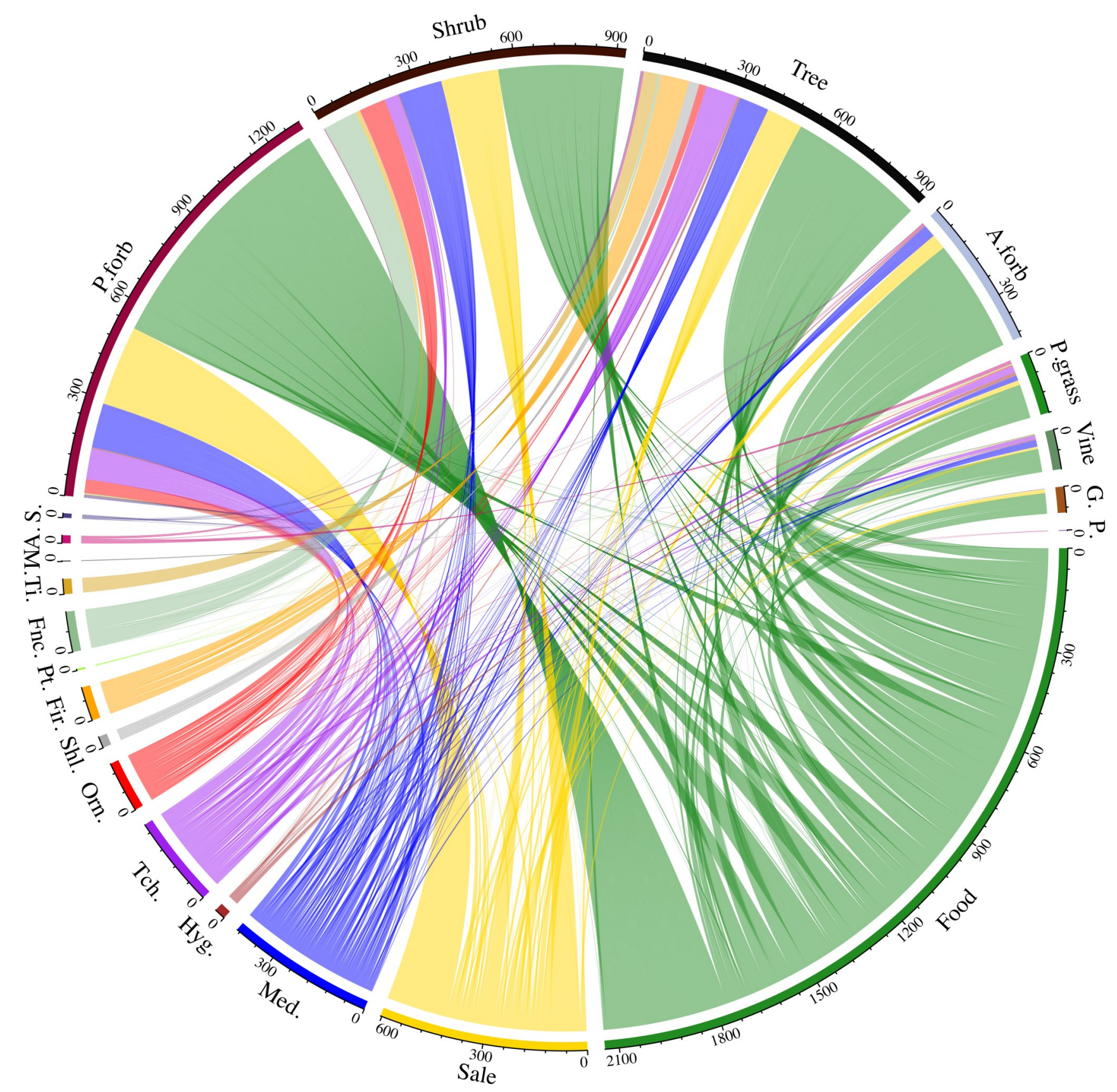

Figure 3 Distribution of 3,961 use reports (UR) among the eight plant types and 14 different use categories in 102 homegardens in southwest Uganda. Eight plant types (top half of circle) include (left to right): perennial forbs (P.forb), shrubs (Shrub), trees (Tree), annual forbs (A.forb), perennial grasses (P.grass), vines (Vine), annual grasses (G.), and palms (P.). Use categories (bottom half of circle) include (left to right): sharing (S.), animal feed (A.), manure for soil fertility (M.), timber and building material (Ti.), fencing (Fnc.), pesticide (Pt.), firewood (Fir.), shelter (Shl.), ornamental (Orn.), technical uses (Tch.), hygienic (Hyg.), medicine (Med.), economic uses (Sale), and food and drink (Food). Scale numbers around the circle indicate UR. 
homegarden structures. This strength may be increased if farmers are offered more access to planting materials for more multipurpose trees and shrubs to increase the multilayered structure.

To the degree homegardens mimic the neighboring forest ecosystems, they can provide ecosystem services and play a potentially important role in the reforestation of the region. The many ecological and social benefits stemming from the high diversity of homegardens, and other similar agroforestry systems, have been demonstrated in SriLanka, where homegardens held similar biomass to wild areas (Mattsson et al. 2013), in Thailand, where shifting cultivation practices were replaced with highly diverse sedentary agriculture in homegardens (Boonkird et al. 1984), and across Indonesia, Sri Lanka, and Vietnam where high diversity homegardens provide rural people with important ecosystem services (Mohri et al. 2013).

The current investigation illustrates the botanical and ethnobotanical diversity of homegardens in Uganda. It describes the current species composition and multilayered nature of homegarden cropping systems. This provides baseline data for future work and could be followed with future analysis of timerelated changes and recommend interventions.

The quantitative ethnobotany tools applied here may be useful for future studies seeking more holistic metrics as indicators of important factors such as cultural value. Such approaches could be beneficial for future studies seeking to gather in-depth local knowledge about botanical resources. They could also be used to formulate interventions to minimize future losses of native biodiversity and traditional ethnobotany knowledge.

The farmers who manage homegardens are engaged in growing a wide range of useful plants (cf. Figure 1), including many native species. Regional and national movements that seek to conserve botanical diversity in the extremely rich eco-systems of Uganda should consider homegardens, both for their role in circa-situm conservation of ecological diversity and for the preservation of associated traditional knowledge. Supporting homegarden managers may prove to be a useful strategy for conservation of the rich botanical agrobiodiversity and agroforestry structures of homegardens. This may be especially important in areas at rainforest and wetland edges such as those in Greater Bushenyi.

\section{Notes}

${ }^{1}$ Categorization by active uses only left some plants out of our analysis. These excluded plants that were mostly weeds, including 3,139 individual plants of around 233 species from six families (some of these remain unidentified). Some plants were excluded from the analysis because they had been recently introduced to the gardens but had not yet produced anything of benefit to the household, e.g., three gardens had plantlets of Artocarpus heterophyllus, one garden had Carica papaya, two had Citrus sinensis, one had Eriobotrya japonica, one had Mangifera indica, six had Persea americana, three had Psidium guajava, one had Solanum lycopersicum, and one had Vangueria apiculata that had not yet produced any fruit (Table 3).

${ }^{2}$ Musa of the AAA and AAA-EAHB groups tended to be used as starchy staples whereas Musa AB, AAB, and $\mathrm{ABB}$ groups tended to be eaten fresh (sweet) or made into juice, beer, or alcohol (Whitney et al. 2016).

\section{Acknowledgements}

This research was financially supported by the Federal Ministry of Education and Research (BMBF), within the collaborative research project GlobE-RELOAD (031A247B). The work was approved by the Ugandan National Council for Science and Technology (Registration number: A 477), the office of the

Table 3 Non-weed plants that were excluded from the analysis because of non-use; 36 stems of eight plant species found in 102 surveyed homegardens in southwest Uganda.

\begin{tabular}{llll}
\hline Family & Botanical name & Number of stems & Number of Gardens \\
\hline Anacardiaceae & Mangifera indica & 1 & 1 \\
Caricaceae & Carica papaya & 3 & 1 \\
Lauraceae & Persea americana & 10 & 6 \\
Moraceae & Artocarpus heterophyllus & 5 & 3 \\
Myrtaceae & Psidium guajava & 9 & 3 \\
Rosaceae & Eriobotrya japonica & 1 & 1 \\
Rubiaceae & Vangueria apiculata & 2 & 1 \\
Rutaceae & Citrus sinensis & 5 & 2 \\
\hline
\end{tabular}


President of Uganda and the approval of the local Regional District Coordinators and Chief Administrative Officers of Bushenyi, Rubirizi, and Sheema. We also thank Antonia Nyamukuru, Carolyne Nakaketo, Dr. Eike Luedeling, Dr. John Tabuti, Dr. Katja Kehlenbeck, Dr. Mary Namaganda, and Olivia Wanyana Maganyi for their advice, feedback, and support throughout this study.

\section{Declarations}

Permissions: Permission/ethical approval granted by the Ugandan National Science Foundation (Registration number: A 477), the President's Office, Regional District Coordinators, Chief Administrative Officers, Local Chairpersons, and farmers.

Sources of funding: This study was funded by the German Federal Ministry of Education and Research (BMBF).

Conflicts of Interest: None declared.

\section{References Cited}

Ahoyo, C. C., T. D. Houehanou, A. S. Yaoitcha, K. Prinz, A. E. Assogbadjo, C. S. G. Adjahossou, F. Hellwig, and M. R. B. Houinato. 2017. A

Quantitative Ethnobotanical Approach Toward Biodiversity Conservation of Useful Woody Species in Wari-Maro Forest Reserve (Benin, West Africa). Environment, Development and Sustainability 1 -20. DOI:10.1007/s10668-017-9990-0.

Alexiades, M. N., and J. W. Sheldon. 1996. Selected Guidelines for Ethnobotanical Research: A Field Manual. New York Botanical Garden, New York.

Boonkird, S. A., E. C. M. Fernandes, and P. K. R. Nair. 1984. Forest Villages: An Agroforestry Approach to Rehabilitating Forest Land Degraded By Shifting Cultivation in Thailand. Agroforestry Systems 2:87-102.

Bruelheide, H., U. Jandt, D. Gries, F. M. Thomas, A. Foetzki, A. Buerkert, G. Wang, X. Zhang, and M. Runge. 2003. Vegetation Changes in a River Oasis on the Southern Rim of the Taklamakan Desert in China Between 1956 and 2000. Phytocoenologia 33:801-818.

Buerkert, A., L. M. Oryakhai, A. A. Filatenko, and K. Hammer. 2006. Cultivation and Taxonomic Classification of Wheat Landraces in the Upper Panjsher Valley of Afganistan after 23 Years of War. Genetic Resources and Crop Evolution 97:53-91.
Buyinza, M. 2009. Land-Use Intensity in the Tree Cropping Homesteads in Kamuli, Eastern Uganda. Agricultural Journal 4(2):46-51.

Carlson, T. J. S., and L. Maffi. 2004. Ethnobotany and Conservation of Biocultural Diversity. New York Botanical Garden, New York.

De Beer, J. J. J., and B. E. Van Wyk. 2011. An Ethnobotanical Survey of the Agter-Hantam, Northern Cape Province, South Africa. South African Journal of Botany 77:741-754. DOI:10.1016/ j.sajb.2011.03.013.

Eilu, G., J. Oriekot, and H. Tushabe. 2007. Conservation of Indigenous Plants Outside Protected Areas in Tororo District, Eastern Uganda. African Journal of Ecology 45:73-78.

Food and Agriculture Organization of the United Nations, eds. 2011. The State of the World's Land and Water Resources for Food and Agriculture (SOLAW) Managing Systems At Risk. Earthscan, London.

Gessler, M., and U. Hodel. 2010. A Case Study of Key Species in Southern Vietnam: Farmer Classification and Management of Agrobiodiversity in Home Gardens. In Home Gardens and Agrobiodiversity, edited by P. B. Eyzaguirre and O. F. Linares, pp. 215-233. Smithsonian Institution Press, Washington, DC.

Goode, P. M. 1989. Edible plants of Uganda: The V alue of Wild and Cultivated Plants as Food. Food and Agriculture Organization (FAO), Rome, Italy.

Gu, Z., L. Gu, R. Eils, M. Schlesner, and B. Brors. 2014. Circlize Implements and Enhances Circular Visualization in R. Bioinformatics 30:2811-2812. DOI:10.1093/bioinformatics/btu393.

Hammer, K., and G. Laghetti. 2005. Genetic ErosionExamples From Italy. Genetic Resources and Crop Evolution 52:629-634.

Johns, T., J. O. Kokwaro, and E. K. Kimanani. 1990. Herbal Remedies of the Luo of Siaya District, Kenya: Establishing Quantitative Criteria for Consensus. Economic Botany 44:369-381.

Kahle, D., and H. Wickham, 2013. ggmap: Spatial Visualization with ggplot2. R Journal 5:144-161.

Kufer, J., H. Förther, E. Pöll, and M. Heinrich. 2005. Historical and Modern Medicinal Plant Uses - the Example of the Chorti Maya and Ladinos in Eastern Guatemala. Journal of Pharmacy and Pharmacology 57:1127-1152. 
Kumar, B. M., and P. K. R. Nair, 2004. The Enigma of Tropical Homegardens. Agroforestry Systems 61:135-152.

Luoga, E. J., E. T. F. Witkowski, and K. Balkwill, 2000. Differential Utilization and Ethnobotany of Trees in Kitulanghalo Forest Reserve and Surrounding Communal Lands, Eastern Tanzania. Economic Botany 54:328-343.

Mattsson, E., M. Ostwald, S. P. Nissanka, and B. Marambe, 2013. Homegardens as a MultiFunctional Land-Use Strategy in Sri Lanka With Focus on Carbon Sequestration. Ambio 42:892902.

Mohri, H., S. Lahoti, O. Saito, A. Mahalingam, N. Gunatilleke, G. Hitinayake, K. Takeuchi, and S. Herath. 2013. Assessment of Ecosystem Services in Homegarden Systems in Indonesia, Sri Lanka, and Vietnam. Ecosystem Services 5:124-136.

Niñez, V. 1985. Introduction: Household Gardens and Small-Scale Food Production. Food and Nutrition Bulletin 7:1-5.

Nyamukuru, A., A. Nabatanzi, S. Mpiira, and J. R. S. Tabuti. 2015. Locally Preferred Woody Species and Their Management in Kiruhura and Arua Districts, Uganda. Ethnobotany Research and Applications 14:49-61.

Oduol, P. A., and J. R. W. Aluma. 1990. The Banana (Musa Spp.) - Coffee Robusta: Traditional Agroforestry System of Uganda. Agroforestry Systems 11:213-226.

Phillips, O., and A. H. Gentry. 1993a. The Useful Plants of Tambopata, Peru: I. Statistical Hypotheses Tests With a New Quantitative Technique. Economic Botany 47:15-32.

Phillips, O., and A. H. Gentry. 1993b. The Useful Plants of Tambopata, Peru: II. Additional Hypothesis Testing in Quantitative Ethnobotany. Economic Botany 47:33-43.

Prance, G. T., W. Baleé, B. M. Boom, and R. L. Carneiro. 1987. Quantitative Ethnobotany and the Case for Conservation in Amazonia. Conservation Biology 1:296-310.

R Core Team. 2016. R: A Language and Environment for Statistical Computing [R version 3.3.2 "Sincere Pumpkin Patch"]. Available at: https://www.Rproject.org/2017. Accessed on December 13, 2017.
Remans, R., D. F. Flynn, F. DeClerck, W. Diru, J. Fanzo, K. Gaynor, I. Lambrecht, J. Mudiope, P. K. Mutuo, P. Nkhoma, D. Siriri, C. Sullivan, and C. A. Palm. 2011. Assessing Nutritional Diversity of Cropping Systems in African Villages. PLOS ONE 6:e21235. DOI:10.1371/journal.pone.0021235.

Scales, B. R., and S. J. Marsden, 2008. Biodiversity in Small-Scale Tropical Agroforests: A Review of Species Richness and Abundance Shifts and the Factors Influencing Them. Environmental Conservation 35:160-172.

Tabuti, J. R. S., V. B. Muwanika, M. Z. Arinaitwe, and T. Ticktin. 2011. Conservation of Priority Woody Species on Farmlands: A Case Study From Nawaikoke Sub-County, Uganda. Applied Geography 31:456-462.

Tabuti, J. R. S. 2012. Important Woody Plant Species, Their Management and Conservation Status in Balawoli Sub-County, Uganda. Ethnobotany Research and Applications 10:269-286.

Tardío, J., and M. Pardo-de-Santayana. 2008. Cultural Importance Indices: A Comparative Analysis Based on the Useful Wild Plants of Southern Cantabria (Northern Spain) 1. Economic Botany 62:24-39.

Teklehaymanot, T., and M. Giday, 2010. Quantitative Ethnobotany of Medicinal Plants Used By Kara and Kwego Semi-Pastoralist People in Lower Omo River Valley, Debub Omo Zone, Southern Nations, Nationalities and Peoples Regional State, Ethiopia. Journal of Ethnopharmacology 130:76-84.

Tugume, P., E. K. Kakudidi, M. Buyinza, J.

Namaalwa, M. Kamatenesi, P. Mucunguzi, and J. Kalema. 2016. Ethnobotanical Survey of Medicinal Plant Species Used by Communities around Mabira Central Forest Reserve, Uganda. Journal of Ethnobiology and Ethnomedicine 12:5. DOI:10.1186/ s13002-015-0077-4.

van Breugel, P., R. Kindt, J. P. B. Lillesø, M. Bingham, S. Demissew, C. Dudley, I. Friis, F. Gachathi, J. Kalema, F. Mbago, H. N. Moshi, J. Mulumba, M. Namaganda, H. J. Ndangalasi, C. K. Ruffo, M. Védaste, R. Jamnadass, and L. Graudal. 2015. Potential Natural Vegetation Map of Eastern Africa (Burundi, Ethiopia, Kenya, Malawi, Rwanda, Tanzania, Uganda and Zambia). Version 2.0. Available at: http://vegetationmap4africa.org. Accessed on March 09, 2016. 
Whitney, C. W., E. Luedeling, J. R. S. Tabuti, A. Nyamukuru, O. Hensel, J. Gebauer, and K. Kehlenbeck. 2017. Crop Diversity in Homegardens of Southwest Uganda and its Importance for Rural Livelihoods. Agriculture and Human Values 35:399-424. DOI:10.1007/s10460017-9835-3.

Whitney, C. W., E. Mukiibi, C. Nakaketo, J. Gebauer, A. M. Rietveld, and K. Kehlenbeck. 2016. Addressing Post-Harvest Losses During Traditional Banana Fermentation for Increased Food Security in Southwest Uganda. Poster presented at Tropentag, September 18-21, 2016. Vienna, Austria. Available at: http:// www.tropentag.de/2016/abstracts/ posters/465.pdf. Accessed on December 15, 2017.
Whitney, C. W., M. M. V. Vang Sin, G. Le Hong, C. Vu Van, K. Barber, and L. Tran Thi. 2014.

Conservation and Ethnobotanical Knowledge of a Hmong Community in Long Lan, Luang Prabang, Lao People's Democratic Republic. Ethnobotany Research and Applications 12:643-658.

DOI:10.17348/era.12.0.643-658.

Whitney, C. W., E. Luedeling, O. Hensel, J. R. S. Tabuti, M. Krawinkel, J. Gebauer, and K. Kehlenbeck. under review. The Role of Homegardens for Food and Nutrition Security in Uganda. Available from cory.whitney@unibonn.de. 